\title{
New faces, old policies in German coalition
}

[MUNICH] Edelgard Bulmahn of the Social Democrats (SPD) seems almost certain to become research minister in Germany's new SPD-Green Party coalition government (see Nature 395, 208; 1998). Wolf-Michael Catenhusen (SPD), a politician with long experience of science policy issues, will act as a state secretary with special responsibilities that include higher education and biotechnology.

Bulmahn has already said that one of her first acts will be to seek an increase in the research budget. But the winds of change are unlikely to blow very hard through the corridors of the ministry following last month's defeat of the Christian Democrats (CDU) after 16 years in power.

There is little to differentiate SPD and CDU research policies, apart from the SPD's greater emphasis on renewable energy and environmental research, and the promise which most view with scepticism - of a significant increase in research funding.

Bulmahn is seen as both bright and personable. A rising star in the SPD, she was recently named the successor to Chancellor Gerhard Schröder as party leader in her home state of Lower Saxony.

Trained as an English teacher, she entered parliament in 1987 and immediately threw herself energetically into research politics. But for many years she stood in the shadow of Catenhusen, who chaired the all-party parliamentary committee for research and technology from 1987 to 1994 and is regarded as one of Germany's leading political experts on biotechnology.

Bulmahn was deputy chair of the research committee from 1990, before serving as chair

\section{Research reactor escapes Green axe... so far}

[MUNICH] Germany's Greens have failed to persuade the Social Democrat Party (SPD), as part of the coalition agreement between the two parties, to take a strongly critical stand on a research reactor being built at the Technical University of Munich. But the two parties did agree last week to phase out the use of nuclear power.

The reactor, FRMII, has come under fire in the past from both political parties for its planned use of highly enriched uranium (HEU) as a source of neutrons. Critics say the fuel could be diverted to make nuclear weapons (see Nature $\mathbf{3 7 9}$, 284; 1996)

The reactor's operating licence is due to be issued by the Bavarian environment ministry next year. In theory, the federal government could veto Bavaria's decision.

"We are not worried about it," says Gert von Hassel, a spokesman for the Technical University of Munich. He says any attempt by the government to stop the reactor from operating would be strongly challenged.

Wolfgang Stöffler, SPD spokesperson on research policy, says the exclusion of

FRMII from the coalition treaty between the two parties does not automatically mean the new government has ruled out a possible veto.

No period has been set for the phasing out of nuclear power - responsible for 36 per cent of Germany's electricity. The costs of such a move could be extremely high. Germany's nuclear industry has said it would sue the government for hundreds of billions of Deutschmarks if it were to revoke the industry's unlimited licences to operate the country's 19 atomic plants.

Quirin Schiermeier

in 1995 and 1996. In 1995 she became chair of the Wissenschaftsforum der Sozialdemokratie, a forum organized by the SPD to educate politicians in science issues. In 1996 she became SPD speaker on research affairs.

Like her predecessor as research minister, Jürgen Rüttgers, Bulmahn believes in the importance of competition, and says she will extend ideas he introduced, such as the Bioregio competition that pitted regions against each other in their bids to be recognized as most competent in biotechnology.

Also like Rüttgers, she is committed to research as a tool for fighting unemployment by promoting innovation. Yet she strongly supports basic research, and was one of its most vociferous defenders in the parliamentary research committee when it came under attack by industrialists in the early 1990s.

Bulmahn is generally well liked by colleagues from other parties. But her honeymoon period may be short, particularly as she plans to immediately put to the test the SPD's election promise to increase the research budget by asking for more than Rüttgers had proposed for the 1999 budget. And rifts with the Green Party are likely to emerge over biotechnology issues.

Alison Abbott

\section{Superconductors make their public debut in US utility network}

[WASHINGTON] The US Department of Energy this week announced the first project to install high-temperature superconducting (HTS) power cables in a utility network. In two years' time, three 130-metre-long HTS cables will replace underground copper cables in an electricity substation in Detroit. The $\$ 5.5$ million demonstration project

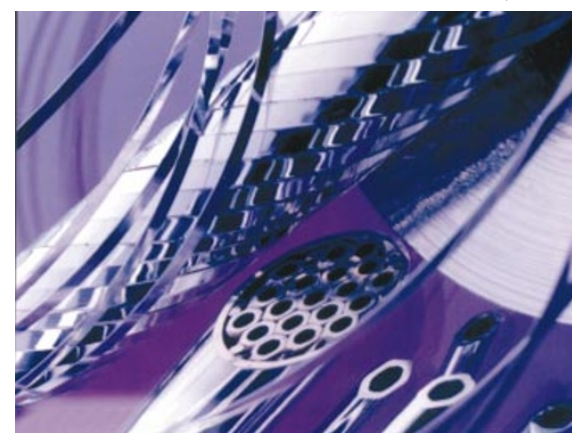

Bright future: superconducting components like these promise reduced transmission costs.

NATURE |VOL $395 \mid 22$ OCTOBER1998 | www.nature.com is jointly funded by the department and private industry. The participants hope that it will be a stepping stone to the large-scale commercialization of the high-temperature oxide superconductors first discovered 12 years ago (see Nature 386, 115-118; 1997).

The 24,000-volt multifilament cables will be manufactured by Pirelli Cables and Systems from HTS wire produced by the American Superconductor Corporation. They will provide three times the powercarrying capacity of the copper cables while occupying the same space.

The contract, and others in the energy department's Superconductivity Program for Electric Systems, constitutes a vote of confidence in HTS technology. The technology has followed a rocky road since widespread hopes of 'electricity too cheap to meter' were sparked by the discovery, in 1987 , of the first superconductor to operate at liquid-nitrogen temperature.
These early hopes were soon dashed by the difficulties of making wire out of the brittle oxide materials, and by obstacles to achieving high current-carrying capacity. But ten years of work on the materials has led to recent successes, including laboratory demonstrations of 50-metre lengths of HTS multifilament cable by Pirelli and by two Japanese companies, Sumitomo Electric Industries and Furukawa Electric.

But the commercialization of HTS power cable still faces an important economic obstacle. Potential manufacturers have estimated that the cost of HTS wire (per ampère metre) would have to decrease 30 fold for power applications to become widespread.

The energy department's programme, which is funded at $\$ 32.5$ million for the fiscal year 1999, aims to help industry overcome this and other obstacles to the commercialization of HTS. Laura Garwin 